\title{
Effect of Dietary Supplementation with Lipids of Different Unsaturation Degree on Feed Efficiency and Milk Fatty Acid Profile in Dairy Sheep
}

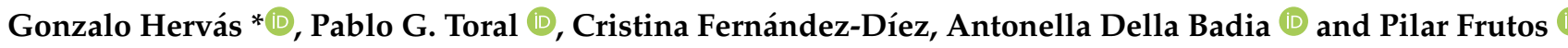 \\ Instituto de Ganadería de Montaña, CSIC-Universidad de León, Finca Marzanas s/n, 24346 Grulleros, Spain; \\ pablo.toral@csic.es (P.G.T.); cristina.fernandez.diez@csic.es (C.F.-D.); a.dellabadia@csic.es (A.D.B.); \\ p.frutos@csic.es (P.F.) \\ * Correspondence: g.hervas@csic.es; Tel.: +34-987-317-156
}

check for updates

Citation: Hervás, G.; Toral, P.G.; Fernández-Díez, C.; Badia, A.D.; Frutos, P. Effect of Dietary

Supplementation with Lipids of Different Unsaturation Degree on Feed Efficiency and Milk Fatty Acid Profile in Dairy Sheep. Animals 2021, 11, 2476. https://doi.org/10.3390/ ani11082476

Academic Editors: George F. W. Haenlein and Jacek Wójtowski

Received: 20 July 2021

Accepted: 22 August 2021

Published: 23 August 2021

Publisher's Note: MDPI stays neutral with regard to jurisdictional claims in published maps and institutional affiliations.

Copyright: (c) 2021 by the authors. Licensee MDPI, Basel, Switzerland. This article is an open access article distributed under the terms and conditions of the Creative Commons Attribution (CC BY) license (https:/ / creativecommons.org/licenses/by/ $4.0 /)$.
Simple Summary: The use of fats derived from palm is becoming very common in dairy sheep farms to increase the energy concentration of the diet and therefore the milk production. However, these fats may negatively affect the nutritional quality of milk, whereas feeding unsaturated oils may improve milk fatty acid profile. In this regard, our results in dairy sheep suggested that using palm fat had no evident disadvantage in terms of milk fatty acid composition compared with a diet without supplementation. Nevertheless, it had no positive effects on production or indicators of feed efficiency (for example, milk yield per unit of feed consumed). By contrast, supplementation with oils rich in unsaturated fatty acids (specifically olive oil and soybean oil) improved milk fatty acid profile, with stronger effects with the use of the most unsaturated fat: soybean oil. For example, the latter oil induced the greatest increases in fatty acids with potentially positive effects on human health (e.g., conjugated linoleic acid). In addition, from a practical point of view, the use of soybean oil might also be recommendable to improve the amount of milk produced per unit of feed consumed, compared with the use of palm fat.

Abstract: Lipids of different unsaturation degree were added to dairy ewe diet to test the hypothesis that unsaturated oils would modulate milk fatty acid (FA) profile without impairing or even improving feed efficiency. To this aim, we examined milk FA profile and efficiency metrics (feed conversion ratio (FCR), energy conversion ratio (ECR), residual feed intake (RFI), and residual energy intake (REI)) in 40 lactating ewes fed a diet with no lipid supplementation (Control) or supplemented with 3 fats rich in saturated, monounsaturated and polyunsaturated FA (i.e., purified palmitic acid (PA), olive oil (OO), and soybean oil (SBO)). Compared with PA, addition of OO decreased milk medium-chain saturated FA and improved the concentration of potentially health-promoting FA, such as cis-9 18:1, trans-11 18:1, cis-9 trans-11 CLA, and 4:0, with no impact on feed efficiency metrics. Nevertheless, FA analysis and decreases in FCR and ECR suggested that SBO supplementation would be a better nutritional strategy to further improve milk FA profile and feed efficiency in dairy ewes. The paradox of differences observed depending on the metric used to estimate feed efficiency (i.e., the lack of variation in RFI and REI vs. changes in FCR and ECR) does not allow solid conclusions to be drawn in this regard.

Keywords: ewe; feed conversion ratio; olive oil; palmitic acid; residual feed intake; soybean oil

\section{Introduction}

In intensive dairy sheep production, feeding systems have moved away from pasturebased to high-concentrate diets, which may affect the nutritional value of milk fat, decreasing the concentration of potentially health-promoting fatty acids (FA), such as cis-9 trans-11 conjugated linoleic acid (CLA), trans-11 18:1, or 18:3n-3 [1-3]. In these production systems, diet supplementation with lipids is also widespread to increase the energy density 
of the ration and therefore production level [4-6]. Furthermore, this nutritional strategy has proven to be very useful to improve milk FA profile by modifying the content of bioactive FA [7-9].

Supplements rich in palmitic acid (mainly as calcium soaps, palm oil, and fractionated FA) are frequently recommended and used by dairy nutritionists, as they seem to offer the best productive responses $[5,10,11]$. However, this recommendation is mostly based on knowledge gained from dairy cows and might be related to the susceptibility of this species to milk fat depression (MFD) induced by unsaturated FA (especially when highconcentrate diets are fed) $[6,12]$. On the contrary, there is evidence that dairy ewes are not prone to this MFD type $[3,8,13,14]$. Thus, in the ovine, substitution of 16:0-rich fats by oils of higher unsaturation degree (e.g., rapeseed or soybean oils) may provide advantages that go beyond enhancing production level, specifically by modulating milk FA profile $[7,15,16]$.

In the last years, an increasing number of researchers in ruminant nutrition have turned their efforts towards prioritizing an improvement in feed efficiency over production level [17-19]. Although there is still very little information on this topic, particularly in dairy ewes [20,21], a recent study has suggested a relationship between feed efficiency and lipid metabolism in the ovine, with certain milk FA being potential biomarkers of this trait (e.g., saturated C4-C14 FA, saturated C4-C14 fatty acids/cis-9 18:1 ratio, or C20-22 n-6 polyunsaturated FA) [22]. Thus, because diet composition has a great influence on the efficiency of feed utilization $[19,23,24]$, re-evaluation of the use of lipid supplements aimed at improving milk FA composition is required to examine their effects on metrics and biomarkers of feed efficiency.

On this basis, this study was conducted in dairy ewes to investigate the effect of dietary supplementation with fat sources of different unsaturation degree (i.e., rich in 16:0, in cis-9 18:1, or in 18:2n-6) on feed efficiency traits and milk FA composition. Our initial hypothesis was that the use of unsaturated fats to modulate milk FA profile in dairy sheep would not impair or would even improve feed efficiency.

\section{Materials and Methods}

\subsection{Animals and Management}

Forty lactating Assaf ewes were housed in individual tie stalls and fed a total mixed ration (TMR) formulated from dehydrated alfalfa (particle size $>4 \mathrm{~cm}$ ) and a concentrate (50:50 forage: concentrate ratio). The TMR contained molasses ( $4 \%$ of diet fresh matter) to hinder selection of dietary components. Clean water was always available and fresh diets were offered daily ad libitum after morning milking. Animals were milked twice daily at approximately 08:30 and 18:30 h in a single-side milking parlor with 10 stalls (DeLaval, Madrid, Spain).

After adaptation of the ewes to the TMR (for 1 month) and to the individual tie stalls (for 1 week), feed intake, body weight (BW), and dairy performance were examined over three weeks (pre-experimental period). Then, the 40 sheep were distributed into 4 groups (10 ewes/group) balanced (mean $\pm \mathrm{SE}$ ) for dry matter intake (DMI; $3.70 \pm 0.08 \mathrm{~kg} /$ day), milk yield $(2.59 \pm 0.10 \mathrm{~kg} /$ day), milk fat and protein concentration $(55.0 \pm 0.8$ and $49.8 \pm 0.5 \mathrm{~g} / \mathrm{kg}$ raw milk, respectively), BW $(74.7 \pm 1.4 \mathrm{~kg})$, and days in milk (DIM; $61.6 \pm 0.7)$. Groups were randomly allocated to 4 dietary treatments consisting of the basal TMR without lipid supplementation (Control) or supplemented with $2 \%$ dry matter (DM) of palm distillate FA (purified commercial product containing $98 \%$ of palmitic acid; PA treatment), $2 \% \mathrm{DM}$ of olive oil (OO treatment) or $2 \% \mathrm{DM}$ of soybean oil (SBO treatment). These dietary treatments were fed over 4 additional weeks (experimental period). This level of oil supplementation was selected based on their potential modulatory effects on milk FA profile $[1,8]$ and to be practical in terms of cost.

The ingredients and chemical composition of the diets are given in Table 1. 
Table 1. Formulation and chemical composition of the experimental diets.

\begin{tabular}{|c|c|c|c|c|}
\hline & \multicolumn{4}{|c|}{ Diet } \\
\hline & Control & PA & OO & SBO \\
\hline \multicolumn{5}{|l|}{ Ingredients, $\mathrm{g} / \mathrm{kg}$ of fresh matter } \\
\hline Dehydrated alfalfa, particle size $>4 \mathrm{~cm}$ & 500 & 491 & 491 & 491 \\
\hline Whole corn grain & 140 & 138 & 138 & 138 \\
\hline Whole barley grain & 100 & 98 & 98 & 98 \\
\hline Soybean meal, solvent $440 \mathrm{~g}$ crude protein $/ \mathrm{kg}$ & 150 & 147 & 147 & 147 \\
\hline Sugar beet pulp, pellets & 50 & 49 & 49 & 49 \\
\hline Molasses, liquid & 40 & 39 & 39 & 39 \\
\hline Vitamin-mineral supplement ${ }^{1}$ & 20 & 20 & 20 & 20 \\
\hline Oil supplement $^{2}$ & 0 & 18 & 18 & 18 \\
\hline \multicolumn{5}{|c|}{ Composition, g/kg diet dry matter (except for dry matter itself; g/kg of fresh matter) } \\
\hline Dry matter & 900 & 906 & 902 & 901 \\
\hline Organic matter & 908 & 908 & 906 & 909 \\
\hline Crude protein & 182 & 176 & 173 & 171 \\
\hline Neutral detergent fiber & 302 & 293 & 301 & 303 \\
\hline Acid detergent fiber & 215 & 213 & 215 & 216 \\
\hline Starch & 130 & 144 & 130 & 137 \\
\hline Total fatty acids & 22.95 & 41.44 & 41.42 & 41.44 \\
\hline $14: 0$ & 0.13 & 0.28 & 0.13 & 0.14 \\
\hline $16: 0$ & 5.10 & 23.77 & 7.50 & 7.07 \\
\hline cis-9 16:1 & 0.04 & 0.04 & 0.26 & 0.06 \\
\hline $18: 0$ & 0.85 & 0.85 & 1.38 & 1.42 \\
\hline cis-9 18:1 & 3.39 & 3.33 & 16.50 & 7.69 \\
\hline cis-11 18:1 & 0.20 & 0.20 & 0.74 & 0.51 \\
\hline cis-9 cis-12 18:2 & 9.42 & 9.23 & 10.85 & 19.26 \\
\hline cis-9 cis-12 cis-15 18:3 & 2.99 & 2.93 & 3.06 & 4.27 \\
\hline $20: 0$ & 0.19 & 0.19 & 0.27 & 0.25 \\
\hline $22: 0$ & 0.18 & 0.18 & 0.21 & 0.27 \\
\hline 24:0 & 0.24 & 0.23 & 0.25 & 0.26 \\
\hline
\end{tabular}

${ }^{1}$ MACROFAC Rumiantes (UP911755130; DSM Nutritional Products S.A., Madrid, Spain). Declared as containing: Ca (285 g/kg), Na (7.5 g/ kg), Fe (3 g/kg), Mn (3 g/kg), Zn (2 g/kg), Mg (1 g/ kg), P (910 mg/kg), Mo (100 mg/kg), Co (67 mg/kg), I (50 mg/kg), S (40 mg/kg), Se $(7 \mathrm{mg} / \mathrm{kg})$, vitamin A (200,000 IU / kg), vitamin D3 (40,000 IU $/ \mathrm{kg})$, vitamin E (667 mg/ kg), ethoxyquin $(12 \mathrm{mg} / \mathrm{kg})$, and propyl gallate (2 mg/kg). ${ }^{2}$ PA: palm distillate fatty acids (SOLAFAM 440, AFAMSA S.A., Mos, Pontevedra, Spain); OO: pure and refined olive oil (Carrefour SA, Madrid, Spain); SBO: soybean oil (OLI-BEEF; INATEGA S.L. Corbillos de la Sobarriba, León, Spain).

\subsection{Measurements and Sampling Procedures}

\subsubsection{Diets}

Representative samples of the 4 experimental diets were collected weekly during the pre-experimental and experimental periods (i.e., 7 samples of the basal diet and 4 samples of the supplemented diets). Samples were stored at $-30^{\circ} \mathrm{C}$, freeze-dried, and again stored frozen to prevent alterations in fatty acid profile before chemical analysis.

\subsubsection{Animal Performance and Feed Efficiency Indicators}

To estimate the individual feed efficiency at the pre-experimental and experimental periods, animal performance was monitored over the whole experiment. The BW of each sheep was recorded once weekly.

The DMI was calculated by weighing the amounts of feed offered and refused by each animal. Then, the net energy content of experimental diets $\left(\mathrm{NE}_{\mathrm{D}}\right)$ was estimated using the INRA [25] tables of nutritive values of feeds and employed to calculate the net energy intake $\left(\mathrm{NEI}=\mathrm{DMI} \times \mathrm{NE}_{\mathrm{D}}\right)$, which is expressed as $\mathrm{MJ}$ of net energy/day.

Total milk produced by each ewe at morning and evening milkings was collected and weighed to calculate milk yield. Composite samples of the daily milk produced by each sheep were prepared according to individual yields in morning and evening milkings twice per week (and three times on the last week of each period). One aliquot of that composite milk was preserved with bronopol (D\&F Control Systems Inc., San Ramon, CA, USA) and 
stored at $4{ }^{\circ} \mathrm{C}$ until analysis for fat, protein, lactose, and total solid concentrations (within 24-72 $\mathrm{h}$ after collection).

On each period, milk yield and milk composition data were used to estimate energycorrected milk $[\mathrm{ECM}=\mathrm{kg} / \mathrm{d}$ of milk yield $\times[(0.0071 \times \mathrm{g} / \mathrm{kg}$ of milk fat $)+(0.0043 \times \mathrm{g} / \mathrm{kg}$ of milk protein $)+0.2224]$, and net energy requirements for lactation $\left(\mathrm{NE}_{\mathrm{L}}=0.686 \times \mathrm{ECM}\right.$, and expressed as MJ of net energy/day), according to INRA [25] equations for sheep. Requirements of protein digestible in the small intestine (PDI) were also estimated according to INRA [25].

The feed conversion ratio (FCR) was calculated as the relationship between mean DMI and ECM on each period, whereas the energy conversion ratio (ECR) was obtained as the relationship between the mean NEI and $\mathrm{NE}_{\mathrm{L}}$ [26].

Residual feed intake (RFI) on each period was estimated as the residuals of the following regression model [27] using the GLM procedure of the SAS software package (version 9.4; SAS Institute Inc., Cary, NC, USA):

$$
\mathrm{DMI}=\mu+a \times \mathrm{ECM}+b \times \mathrm{MBW}+c \times \mathrm{BWC}+d \times \mathrm{DIM}+\mathrm{RFI}
$$

where DMI represents the mean dry matter intake over the period $(\mathrm{kg} /$ day); $\mu$ is the intercept; ECM is the energy-corrected milk (kg/day); MBW is the mean metabolic body weight $\left(\mathrm{BW}^{0.75} ; \mathrm{kg}\right)$; BWC is body weight change over the period $(\mathrm{kg})$; DIM are days in milk; RFI is the residuals; and $a, b, c$, and $d$ are the regression coefficients.

The same procedure was used to estimate the residual energy intake (REI) as the residuals of the following regression model:

$$
\mathrm{NEI}=\mu+a \times \mathrm{ECM}+b \times \mathrm{MBW}+c \times \mathrm{BWC}+d \times \mathrm{DIM}+\mathrm{REI}
$$

where NEI represents the mean net energy intake over the period (MJ/day); $\mu$ is the intercept; ECM is the energy-corrected milk (kg/day); MBW is the mean metabolic body weight $\left(\mathrm{BW}^{0.75} ; \mathrm{kg}\right)$; BWC is body weight change over the period $(\mathrm{kg})$; DIM are days in milk; REI is the residuals; and $a, b, c$, and $d$ are the regression coefficients.

\subsubsection{Milk FA Composition}

On the last week of each period, aliquots of composite milk from each ewe were collected on 3 consecutive days and stored without preservative at $-30{ }^{\circ} \mathrm{C}$ until fat extraction for FA composition analysis.

\subsection{Laboratory Analysis}

\subsubsection{Experimental Diets}

Feed samples were prepared (ISO 6498:2012) and analyzed for DM (ISO 6496:1999), ash (ISO 5984:2002), and crude protein (ISO 5983-2:2009). The concentrations of neutraldetergent fiber (NFD) and acid-detergent fiber (ADF) were sequentially determined using an Ankom ${ }^{2000}$ fiber analyzer (Ankom Technology Methods 13 and 12, respectively; Ankom Technology Corp., Macedon, NY, USA); the former was assayed with sodium sulfite and $\alpha$-amylase, and both NDF and ADF were expressed with residual ash. Starch content was analyzed by a total starch assay kit obtained from Megazyme (K-TSTA; Megazyme Intl. Ireland Ltd., Wicklow, Ireland).

The fatty acid methyl esters (FAME) of lipid in freeze-dried TMR samples were prepared in a 1-step extraction-transesterification procedure [28], adding $1 \mathrm{mg}$ of cis-12 13:1 (10-1301-9, Larodan Fine Chemicals AB, Solna, Sweden) as an internal standard. The methyl esters were separated and quantified using a gas chromatograph (Agilent 7890A GC System, Santa Clara, CA, USA) equipped with a flame ionization detector and a $100 \mathrm{~m}$ fused silica capillary column $(0.25 \mathrm{~mm}$ i.d., $0.2 \mu \mathrm{m}$ film thickness; CP-SIL 88, Varian Ibérica S.A., Madrid, Spain), and hydrogen as fuel and carrier gas (207 kPa, $2.1 \mathrm{~mL} / \mathrm{min})$. Total FAME profile in a $2 \mu \mathrm{L}$ sample volume at a split ratio of 1:50 was determined using a temperature gradient program [28]: following sample injection, column temperature was 
maintained at $70{ }^{\circ} \mathrm{C}$ for $4 \mathrm{~min}$, increased at a rate of $8{ }^{\circ} \mathrm{C} / \mathrm{min}$ to $110{ }^{\circ} \mathrm{C}$, raised to $170{ }^{\circ} \mathrm{C}$ at a rate of $5^{\circ} \mathrm{C} / \mathrm{min}$, held at $170^{\circ} \mathrm{C}$ for $10 \mathrm{~min}$, increased at $4^{\circ} \mathrm{C} / \mathrm{min}$ to a final temperature of $240{ }^{\circ} \mathrm{C}$ that was maintained for $14.5 \mathrm{~min}$. Peaks were identified based on retention time comparisons with commercially available standards (GLC463, Nu-Chek Prep, Elysian, MN, USA; 18919-1AMP Supelco, Sigma-Aldrich, Madrid, Spain).

\subsubsection{Milk Composition}

Milk samples were analyzed for fat, protein, lactose, and total solid concentration by infrared spectrophotometry (ISO 9622:1999) using a MilkoScan FT6000 (Foss, Hillerød, Denmark).

Lipids in $1 \mathrm{~mL}$ of milk were extracted and converted to FAME by base-catalyzed transesterification [28]. Total FAME profile was determined using the same chromatograph and temperature gradient program applied for the analysis of feed, but isomers of 18:1 were further resolved in a separate analysis under isothermal conditions at $170{ }^{\circ} \mathrm{C}$ [26]. All peaks were identified based on retention time comparisons with commercially available standards (GLC463, U-37-M, U-43-M, U-45-M and U-64-M, from Nu-Chek Prep; 189191AMP Supelco, L6031, L8404 and O5632, from Sigma-Aldrich; and 11-1600-8, 20-2024-1, 20-2210-9, 20-2305-1-4, 21-1211-7, 21-1413-7, 21-1614-7, 21-1615-7 and BR mixtures 2 and 3, from Larodan Fine Chemicals AB), with reference samples for which the FA composition was determined based on gas chromatography analysis of FAME and GC-MS analysis of corresponding 4,4-dimethyloxazoline derivatives $[29,30]$, and with chromatograms reported in the literature [28].

\subsection{Statical Analysis}

Statistical analysis was performed using the MIXED procedure of SAS software package (version 9.4).

Data were analyzed by one-way analysis of covariance with a model that included the fixed effect of the 4 experimental treatments (Control, PA, OO and SBO) and measurements on the pre-experimental period as a covariate, as follows:

$$
y_{i j k}=\mu+\alpha_{i}+d_{j(i)}+\left(b+\varphi_{j}\right) x_{i j}+\mathrm{e}_{i j k}
$$

where $y_{i j k}$ is the dependent variable measured at time $k$ (experimental period) on the $j$ th animal assigned to the $i$ th diet, $\mu$ the overall mean effect, $\alpha_{i}$ the $i$ th fixed diet effect, $d_{j(i)}$ the random effect of the $j$ th animal within the $i$ th diet, $b$ the common regression coefficient of initial value of $x_{i j}, \varphi_{j}$ the slope deviation of the $i$ th diet from common slope $b, x_{i j}$ the initial record measure (pre-experimental period) of the $j$ th animal on the $i$ th diet, and $\mathrm{e}_{i j k}$ the random error associated with the $j$ th animal assigned to the $i$ th diet at time $k$.

Means were separated through the pairwise differences (pdiff) option of the least squares means (lsmeans) statement of the MIXED procedure and adjusted for multiple comparisons using Bonferroni's method. Differences were declared significant at $p<0.05$ and considered a trend toward significance at $0.05 \leq p<0.10$. Least squares means are reported.

\section{Results}

\subsection{Animal Performance and Feed Efficiency Indicators}

As shown in Table 2, diet supplementation with lipids affected FCR, with a 12\% decrease in SBO treatment compared with the Control and PA $(p=0.012)$. Similarly, ECR tended to be $11 \%$ lower in SBO than in PA treatment $(p=0.052)$. On the contrary, residual traits (RFI and REI) were not significantly modified by the inclusion of lipids in the TMR $(p>0.10)$. 
Table 2. Animal performance in dairy ewes fed a total mixed ration without lipid supplementation (Control) or supplemented with $2 \%$ dry matter (DM) of palm distillate fatty acids (PA), olive oil (OO), and soybean oil (SBO).

\begin{tabular}{|c|c|c|c|c|c|c|}
\hline & \multicolumn{4}{|c|}{ Diet } & \multirow[b]{2}{*}{ SED $^{1}$} & \multirow[b]{2}{*}{$p$-Value } \\
\hline & Control & PA & OO & SBO & & \\
\hline Feed conversion ratio (FCR) & $1.76^{\mathrm{a}}$ & $1.73^{\mathrm{a}}$ & $1.67^{\mathrm{ab}}$ & $1.54^{\mathrm{b}}$ & 0.07 & 0.012 \\
\hline Energy conversion ratio (ECR) & 2.39 & 2.48 & 2.39 & 2.21 & 0.09 & 0.052 \\
\hline Residual feed intake (RFI) & 0.014 & -0.100 & 0.045 & -0.114 & 0.094 & 0.233 \\
\hline Residual energy intake (REI) & -0.036 & 1.362 & 0.317 & 0.528 & 0.819 & 0.353 \\
\hline $\mathrm{DM}$ intake, $\mathrm{kg} / \mathrm{d}$ & 3.32 & 3.26 & 3.33 & 3.06 & 0.11 & 0.066 \\
\hline Body weight, kg & 75.4 & 75.5 & 75.0 & 76.5 & 0.6 & 0.122 \\
\hline Body weight change, $\mathrm{kg}$ & 7.2 & 5.7 & 7.3 & 3.7 & 1.4 & $0.044^{2}$ \\
\hline \multicolumn{7}{|l|}{ Yield, kg/d } \\
\hline Milk & 2.40 & 2.42 & 2.48 & 2.35 & 0.10 & 0.590 \\
\hline Energy corrected milk (ECM) & 2.01 & 2.08 & 2.13 & 2.11 & 0.09 & 0.611 \\
\hline Fat & $0.132^{b}$ & $0.138^{a b}$ & $0.150^{\mathrm{a}}$ & $0.144^{\mathrm{ab}}$ & 0.006 & 0.039 \\
\hline Protein & 0.118 & 0.115 & 0.121 & 0.114 & 0.004 & 0.415 \\
\hline Lactose & 0.122 & 0.121 & 0.126 & 0.118 & 0.005 & 0.528 \\
\hline Total solids & 0.395 & 0.396 & 0.422 & 0.399 & 0.016 & 0.296 \\
\hline \multicolumn{7}{|l|}{ Fatty acid yield, $\mathrm{mmol} / \mathrm{d}$} \\
\hline Total fatty acids & $541^{c}$ & 579 bc & $660^{\mathrm{a}}$ & $633^{a b}$ & 28 & $<0.001$ \\
\hline$<\mathrm{C} 16$ & $283^{b}$ & $292^{b}$ & $337^{\text {a }}$ & $320 \mathrm{ab}$ & 15 & 0.004 \\
\hline $\mathrm{C} 16$ & $148^{\mathrm{b}}$ & $172^{a}$ & $145^{\mathrm{b}}$ & $135^{\mathrm{b}}$ & 8 & $<0.001$ \\
\hline$>\mathrm{C} 16$ & $113^{b}$ & $115^{b}$ & $177^{\mathrm{a}}$ & $177^{\mathrm{a}}$ & 11 & $<0.001$ \\
\hline \multicolumn{7}{|l|}{ Milk composition, $\mathrm{g} / \mathrm{kg}$ raw milk } \\
\hline Fat & $54.8^{\mathrm{c}}$ & $56.8^{\mathrm{bc}}$ & $60.3^{a b}$ & $61.7^{\mathrm{a}}$ & 1.7 & 0.001 \\
\hline Protein & 48.6 & 47.6 & 49.1 & 48.5 & 0.9 & 0.388 \\
\hline Lactose & 50.6 & 49.7 & 50.7 & 50.3 & 0.7 & 0.475 \\
\hline Total solids & 163.8 & 163.3 & 169.7 & 170.2 & 2.7 & $0.016^{2}$ \\
\hline
\end{tabular}

${ }^{\mathrm{a}-\mathrm{c}}$ Within a row, different superscripts indicate differences $(p<0.05)$ due to the effect of diet. ${ }^{1}$ SED $=$ standard error of the difference. ${ }^{2}$ In the pairwise analysis, no significant differences were found after adjustment for multiple comparisons using Bonferroni's method.

Feed intake tended to be affected by diet $(p=0.066)$, but no differences or trends toward difference were observed in pairwise comparisons after adjustment using Bonferroni's method. Body weight and yields of milk, ECM, protein, lactose and total solids remained unaffected by treatment $(p>0.10)$. However, compared with the Control, milk fat yield was $12 \%$ greater in $\mathrm{OO}(p=0.039)$, with an increase in the molar production of $<\mathrm{C} 16$ and $>\mathrm{C} 16$ FA $(p<0.01)$. Supplementation with SBO also improved milk > C16 FA yield compared with the Control $(p<0.001)$, whereas the production of C16 FA was greater in PA than in other treatments $(p<0.001)$. In addition, milk fat content was 10 and $13 \%$ higher in $\mathrm{OO}$ and $\mathrm{SBO}$, respectively, compared with the Control $(p=0.001)$, but no significant effects were observed in the concentration of milk protein, lactose, and total solids.

Protein balance was positive in the four experimental treatments: ewes consumed on average $127 \pm 3 \%$ of their estimated PDI requirements.

\subsection{Milk Short- and Medium-Chain FA}

Table 3 reports the content of milk short- and medium-chain FA, which were differently affected by lipid supplementation. Specifically, ewes on PA treatment showed the greatest proportions of 16:0 and cis-9 16:1 in milk ( $p<0.001)$, but 12:0, 14:0, and cis-7 14:1 concentrations were lower than in the Control $(p<0.001)$. Reductions in these mediumchain FAs were greater in $\mathrm{OO}$ and SBO treatments, which showed the lowest content of most FAs with 10 to 16 carbon atoms, such as 10:0, cis-9 12:1, and 16:0 $(p<0.05)$, except for the increase in trans-9 16:1 in SBO relative to other diets $(p<0.001)$ and the lack of variation in cis-9 10:1 and trans-5 to -8 16:1 ( $p>0.10)$. Compared with the Control, the milk concentration of 4:0 was increased in $\mathrm{OO}$ and SBO $(p<0.001)$, and that of 6:0 in $\mathrm{SBO}(p=0.001)$. On 
average, lipid supplements caused an 11\% decrease in the sum of saturated C4-C14 FA (i.e., those mostly derived from mammary de novo synthesis) relative to the Control $(p<0.001)$.

Table 3. Milk short- and medium-chain fatty acids ( $\mathrm{g} / 100 \mathrm{~g}$ of total fatty acids) in dairy ewes fed a total mixed ration without lipid supplementation (Control) or supplemented with $2 \%$ dry matter (DM) of palm distillate fatty acids (PA), olive oil (OO), and soybean oil (SBO).

\begin{tabular}{|c|c|c|c|c|c|c|}
\hline & \multicolumn{4}{|c|}{ Diet } & \multirow{2}{*}{ SED $^{1}$} & \multirow{2}{*}{$p$-Value } \\
\hline & Control & PA & OO & SBO & & \\
\hline $4: 0$ & $3.24^{b}$ & $3.39 \mathrm{ab}$ & $3.44^{\mathrm{a}}$ & $3.53^{a}$ & 0.07 & $<0.001$ \\
\hline $6: 0$ & $2.86^{b}$ & $2.85^{b}$ & $3.04^{\mathrm{ab}}$ & $3.10^{\mathrm{a}}$ & 0.07 & 0.001 \\
\hline 8:0 & 3.00 & 2.86 & 3.13 & 3.10 & 0.11 & 0.074 \\
\hline $10: 0$ & $10.90^{\mathrm{a}}$ & $9.93^{a b}$ & $9.65^{b}$ & $9.43^{b}$ & 0.38 & 0.003 \\
\hline cis-9 10:1 & 0.305 & 0.291 & 0.288 & 0.284 & 0.016 & 0.576 \\
\hline $12: 0$ & $6.95^{\mathrm{a}}$ & $6.04^{b}$ & $5.09^{c}$ & $5.05^{c}$ & 0.31 & $<0.001$ \\
\hline cis-9 12:1 & $0.122^{a}$ & $0.111^{\mathrm{a}}$ & $0.083^{b}$ & $0.081^{b}$ & 0.008 & $<0.001$ \\
\hline trans-9 12:1 & $0.056^{\mathrm{a}}$ & $0.052^{\mathrm{a}}$ & $0.042^{b}$ & $0.041^{b}$ & 0.003 & $<0.001$ \\
\hline $14: 0$ & $13.21^{\mathrm{a}}$ & $11.69^{\mathrm{b}}$ & $10.74^{\mathrm{c}}$ & $10.61^{c}$ & 0.34 & $<0.001$ \\
\hline cis-7 14:1 & $0.022^{a}$ & $0.019^{b}$ & $0.017^{b c}$ & $0.015^{c}$ & 0.001 & $<0.001$ \\
\hline cis-9 14:1 & $0.195^{\mathrm{a}}$ & $0.177^{a b}$ & $0.152^{b}$ & $0.151^{b}$ & 0.011 & $<0.001$ \\
\hline cis-12 14:1 & $0.110^{\mathrm{a}}$ & $0.102^{\mathrm{a}}$ & $0.078^{\mathrm{b}}$ & $0.073^{b}$ & 0.007 & $<0.001$ \\
\hline $16: 0$ & $28.94^{b}$ & $32.84^{a}$ & $24.98^{c}$ & $24.25^{c}$ & 0.75 & $<0.001$ \\
\hline trans-5 16:1 & 0.028 & 0.028 & 0.028 & 0.023 & 0.002 & $0.027^{2}$ \\
\hline trans $-6+7+816: 1$ & 0.106 & 0.093 & 0.130 & 0.126 & 0.019 & 0.152 \\
\hline trans-9 16:1 & $0.054^{\mathrm{b}}$ & $0.060^{\mathrm{b}}$ & $0.086^{\mathrm{b}}$ & $0.146^{\mathrm{a}}$ & 0.013 & $<0.001$ \\
\hline cis-9 16:1 & $0.758^{\mathrm{b}}$ & $0.849^{\mathrm{a}}$ & $0.666^{c}$ & $0.649^{c}$ & 0.032 & $<0.001$ \\
\hline cis-11 16:1 & $0.016^{\mathrm{a}}$ & $0.015^{\mathrm{a}}$ & $0.012^{b}$ & $0.012^{b}$ & 0.001 & $<0.001$ \\
\hline cis-13 16:1 & $0.013^{\mathrm{a}}$ & $0.012^{\mathrm{a}}$ & $0.009^{b}$ & $0.010^{\mathrm{b}}$ & 0.001 & $<0.001$ \\
\hline$\sum$ saturated C4-C14 fatty acids & $40.14^{\mathrm{a}}$ & $36.81^{\mathrm{b}}$ & $35.07^{\mathrm{b}}$ & $34.81^{b}$ & 0.99 & $<0.001$ \\
\hline
\end{tabular}

${ }^{\mathrm{a}-\mathrm{c}}$ Within a row, different superscripts indicate differences $(p<0.05)$ due to the effect of diet. ${ }^{1}$ SED $=$ standard error of the difference. ${ }^{2}$ In the pairwise analysis, no significant differences were found after adjustment for multiple comparisons using Bonferroni's method.

\subsection{Milk C18 FA}

Dietary treatments showed clearly divergent effects of milk C18 FA (Table 4), and most FA within this group were more abundant in $\mathrm{OO}$, and specially in SBO, compared with control and PA $(p<0.05)$. For example, 18:0, trans-9 and trans-10 18:1, or trans-10 trans-14 18:2 were similarly increased by the two unsaturated lipid supplements $(p<0.001)$, but SBO caused the greatest increment in the concentrations of trans-11 18:1, other 18:1 isomers with $\Delta 12$ to $\Delta 16$ double bonds, non-conjugated 18:2 isomers, and cis-9 trans-11, trans-9 cis-11 and trans-10 cis-12 CLA $(p<0.01)$. However, the highest proportions of cis-9 18:1 and of the minor 10-oxo-18:0 and trans-4 to trans-8 18:1 were found in OO treatment $(p<0.001)$. This latter oil negatively affected the percentage of milk cis-9 cis-12 18:2 and cis-9 cis-12 cis-15 18:3 ( $p<0.001)$, whereas SBO improved cis-9 cis-12 18:2 content $(p<0.001)$. On the other hand, cis-11 18:1, trans-11 cis-13 CLA and trans-9 trans-12 trans-15 18:3 remained unaffected by dietary treatment $(p>0.10)$.

Table 4. Milk C18 fatty acids (g/100 g of total fatty acids) in dairy ewes fed a total mixed ration without lipid supplementation (Control) or supplemented with $2 \%$ dry matter (DM) of palm distillate fatty acids (PA), olive oil (OO), and soybean oil (SBO).

\begin{tabular}{|c|c|c|c|c|c|c|}
\hline & \multicolumn{4}{|c|}{ Diet } & \multirow{2}{*}{ SED $^{1}$} & \multirow{2}{*}{$p$-Value } \\
\hline & Control & PA & $\mathrm{OO}$ & SBO & & \\
\hline $18: 0$ & $6.10^{b}$ & $5.57^{b}$ & $9.51^{a}$ & $8.41^{\mathrm{a}}$ & 0.43 & $<0.001$ \\
\hline 10-охо-18:0 & $0.012^{b c}$ & $0.006^{c}$ & $0.024^{\mathrm{a}}$ & $0.018^{a b}$ & 0.003 & $<0.001$ \\
\hline 13-охо-18:0 & $0.007^{a}$ & $0.003^{b}$ & $0.004^{\mathrm{ab}}$ & $0.005^{a b}$ & 0.001 & 0.017 \\
\hline cis-9 18:1 ${ }^{2}$ & $10.43^{c}$ & $10.62^{c}$ & $15.56^{\mathrm{a}}$ & $13.66^{b}$ & 0.65 & $<0.001$ \\
\hline cis-11 18:1 & 0.329 & 0.349 & 0.388 & 0.356 & 0.023 & 0.106 \\
\hline
\end{tabular}


Table 4. Cont.

\begin{tabular}{|c|c|c|c|c|c|c|}
\hline & \multicolumn{4}{|c|}{ Diet } & \multirow{2}{*}{ SED $^{1}$} & \multirow{2}{*}{$p$-Value } \\
\hline & Control & PA & OO & SBO & & \\
\hline cis-12 18:1 & $0.234^{b}$ & $0.221^{b}$ & $0.254^{b}$ & $0.670^{\mathrm{a}}$ & 0.033 & $<0.001$ \\
\hline cis-13 18:1 & $0.052^{\mathrm{c}}$ & $0.047^{c}$ & $0.066^{\mathrm{b}}$ & $0.085^{\mathrm{a}}$ & 0.004 & $<0.001$ \\
\hline cis-15 18:1 & $0.085^{b c}$ & $0.080^{c}$ & $0.101^{b}$ & $0.153^{\mathrm{a}}$ & 0.006 & $<0.001$ \\
\hline cis-16 18:1 & $0.038^{b c}$ & $0.034^{\mathrm{c}}$ & $0.046^{b}$ & $0.071^{\mathrm{a}}$ & 0.003 & $<0.001$ \\
\hline trans-4 18:1 & $0.015^{c}$ & $0.013^{c}$ & $0.061^{\mathrm{a}}$ & $0.033^{b}$ & 0.004 & $<0.001$ \\
\hline trans-5 18:1 & $0.011^{c}$ & $0.009^{c}$ & $0.046^{\mathrm{a}}$ & $0.027^{\mathrm{b}}$ & 0.003 & $<0.001$ \\
\hline trans $-6+7+818: 1$ & $0.158^{c}$ & $0.154^{c}$ & $0.574^{\mathrm{a}}$ & $0.403^{b}$ & 0.028 & $<0.001$ \\
\hline trans-9 18:1 & $0.142^{b}$ & $0.122^{b}$ & $0.391^{\mathrm{a}}$ & $0.337^{\mathrm{a}}$ & 0.023 & $<0.001$ \\
\hline trans-10 18:1 & $0.232^{b}$ & $0.212^{b}$ & $0.490^{\mathrm{a}}$ & $0.548^{a}$ & 0.027 & $<0.001$ \\
\hline trans-11 18:1 & $0.597^{c}$ & $0.639 \mathrm{bc}$ & $1.119^{\mathrm{b}}$ & $1.888^{\mathrm{a}}$ & 0.177 & $<0.001$ \\
\hline trans-12 18:1 & $0.258^{c}$ & $0.241^{\mathrm{c}}$ & $0.541^{\mathrm{b}}$ & $0.647^{\mathrm{a}}$ & 0.029 & $<0.001$ \\
\hline trans-15 18:1 & $0.188^{c}$ & $0.175^{c}$ & $0.292^{b}$ & $0.396^{\mathrm{a}}$ & 0.021 & $<0.001$ \\
\hline trans $-16+$ cis-14 18:1 & $0.292^{c}$ & $0.259^{c}$ & $0.385^{b}$ & $0.525^{\mathrm{a}}$ & 0.020 & $<0.001$ \\
\hline cis-9 cis-12 18:2 & $2.33^{\mathrm{b}}$ & $2.26^{\mathrm{b}}$ & $1.81^{\mathrm{c}}$ & $2.71^{\mathrm{a}}$ & 0.09 & $<0.001$ \\
\hline cis-9 trans-12 18:2 & $0.033^{c}$ & $0.030^{c}$ & $0.044^{b}$ & $0.064^{\mathrm{a}}$ & 0.004 & $<0.001$ \\
\hline cis-9 trans $-1318: 2^{3}$ & $0.198^{c}$ & $0.185^{c}$ & $0.257^{b}$ & $0.372^{\text {a }}$ & 0.017 & $<0.001$ \\
\hline cis-9 trans-14 18:2 & $0.100^{c}$ & $0.096^{\mathrm{c}}$ & $0.128^{\mathrm{b}}$ & $0.175^{\mathrm{a}}$ & 0.007 & $<0.001$ \\
\hline trans- 9 cis- 12 18:2 & $0.025 \mathrm{bc}$ & $0.024^{\mathrm{c}}$ & $0.031^{\mathrm{b}}$ & $0.047^{\mathrm{a}}$ & 0.002 & $<0.001$ \\
\hline trans- 11 cis- 15 + trans-10 cis-15 18:2 & $0.063^{\mathrm{b}}$ & $0.057^{\mathrm{b}}$ & $0.060^{\mathrm{b}}$ & $0.116^{\mathrm{a}}$ & 0.009 & $<0.001$ \\
\hline trans-12 cis-15 18:2 & $0.014^{\mathrm{b}}$ & $0.013^{\mathrm{b}}$ & $0.015^{\mathrm{b}}$ & $0.023^{\mathrm{a}}$ & 0.002 & $<0.001$ \\
\hline trans-10 trans-14 18:2 & $0.012^{b}$ & $0.010^{\mathrm{b}}$ & $0.018^{\mathrm{a}}$ & $0.018^{\mathrm{a}}$ & 0.001 & $<0.001$ \\
\hline trans-11 trans-15 18:2 & $0.012^{b}$ & $0.011^{\mathrm{b}}$ & $0.016^{\mathrm{b}}$ & $0.028^{\mathrm{a}}$ & 0.002 & $<0.001$ \\
\hline cis-9 trans-11 CLA ${ }^{4}$ & $0.325^{c}$ & $0.334^{c}$ & $0.554^{\mathrm{b}}$ & $0.880^{\mathrm{a}}$ & 0.077 & $<0.001$ \\
\hline trans-9 cis-11 CLA & $0.013^{\mathrm{b}}$ & $0.012^{b}$ & $0.017^{\mathrm{ab}}$ & $0.021^{\mathrm{a}}$ & 0.002 & 0.001 \\
\hline trans-10 cis-12 CLA & $0.003^{\mathrm{b}}$ & $0.003^{\mathrm{b}}$ & $0.003^{b}$ & $0.006^{\mathrm{a}}$ & 0.001 & 0.002 \\
\hline trans-11 cis-13 CLA ${ }^{5}$ & 0.011 & 0.010 & 0.010 & 0.013 & 0.002 & 0.433 \\
\hline trans- 11 trans-13 CLA & $0.053^{a b}$ & $0.058^{\mathrm{a}}$ & $0.034^{\mathrm{c}}$ & $0.043^{b c}$ & 0.005 & $<0.001$ \\
\hline$\sum$ other trans, trans CLA ${ }^{6}$ & $0.011^{\mathrm{b}}$ & $0.010^{\mathrm{b}}$ & $0.017^{\mathrm{a}}$ & $0.017^{\mathrm{a}}$ & 0.002 & $<0.001$ \\
\hline cis-9 cis-12 cis-15 18:3 & $0.667^{\mathrm{a}}$ & $0.643^{\mathrm{a}}$ & $0.482^{b}$ & $0.635^{\mathrm{a}}$ & 0.029 & $<0.001$ \\
\hline cis-9 trans- 11 trans -15 18:3 & $0.006^{\mathrm{b}}$ & $0.006^{\mathrm{b}}$ & $0.006^{\mathrm{b}}$ & $0.012^{\mathrm{a}}$ & 0.001 & $<0.001$ \\
\hline cis-9 trans-12 cis-15 18:3 & $0.012^{b}$ & $0.013^{a b}$ & $0.016^{\mathrm{a}}$ & $0.014^{\mathrm{ab}}$ & 0.001 & 0.035 \\
\hline trans -9 cis- 12 cis- $1518: 3^{7}$ & $0.007^{\mathrm{b}}$ & $0.006^{\mathrm{b}}$ & $0.011^{\mathrm{a}}$ & $0.013^{\mathrm{a}}$ & 0.001 & $<0.001$ \\
\hline trans-9 trans- 12 trans $-1518: 3$ & 0.002 & 0.002 & 0.005 & 0.002 & 0.002 & 0.258 \\
\hline saturated C4-C14 fatty acids/cis-9 18:1 & $3.88^{\mathrm{a}}$ & $3.58^{a}$ & $2.31^{b}$ & $2.62^{b}$ & 0.23 & $<0.001$ \\
\hline
\end{tabular}

${ }^{\mathrm{a}-\mathrm{c}}$ Within a row, different superscripts indicate differences $(p<0.05)$ due to the effect of diet. ${ }^{1}$ SED $=$ standard error of the difference.

${ }^{2}$ Coelutes with trans-13 + 14 18:1. ${ }^{3}$ Coelutes with cis-10 trans-14, trans-10 trans-13, and trans-11 trans-14 18:2. ${ }^{4}$ Contains trans-7 cis-9 and trans-8 cis-10 CLA as minor isomers. ${ }^{5}$ Coelutes with an unidentified component. ${ }^{6}$ Sum of trans- 8 trans-10, trans- 9 trans -11 , and trans- 10 trans-12 CLA. ${ }^{7}$ Coelutes with cis-5 20:1.

Finally, the ratio between saturated C4-C14 FA and cis-9 18:1 was 34\% lower in OO and SBO than in Control and PA treatments $(p<0.001)$.

\subsection{Other Milk FA}

Very long-chain FA are reported in Table 5. Compared with the Control, PA only affected (i.e., decreased) 24:0 concentration, which was also reduced in $\mathrm{OO}$ treatment $(p=0.004)$. Milk 20:2n-6, 22:5n-6, and the sum of C20-22 n-6 polyunsaturated FA were greater in PA than $\mathrm{OO}(p=0.034)$. On the contrary, this latter treatment and SBO resulted in the greatest milk concentration of cis-11 and trans-11 20:1, and 20:4n-3 and cis-13 22:1 were increased in SBO treatment $(p<0.01)$.

The sums of milk odd- and branched-chain FA were negatively affected by the inclusion of unsaturated oils $(p<0.001$; Table 6$)$. Regarding individual FA within these two groups, the content of 11:0, iso 13:0, 15:0, anteiso 15:0, iso 15:0, or 21:0 decreased in $\mathrm{OO}$ and SBO relative to the Control $(p<0.05)$, whereas anteiso 13:0 and anteiso 17:0 were only reduced in $\mathrm{OO}(p<0.05)$, and 4,8,12-trimethyl-13:0 increased in SBO relative to other 
treatments $(p=0.002)$. On the other hand, PA caused no significant variation in milk oddand branched-chain FA compared with the Control, except for a decrease in 23:0 $(p<0.001)$.

Table 5. Milk very long-chain fatty acids ( $\mathrm{g} / 100 \mathrm{~g}$ of total fatty acids) in dairy ewes fed a total mixed ration without lipid supplementation (Control) or supplemented with $2 \%$ dry matter (DM) of palm distillate fatty acids (PA), olive oil (OO), and soybean oil (SBO).

\begin{tabular}{|c|c|c|c|c|c|c|}
\hline & \multicolumn{4}{|c|}{ Diet } & \multirow{2}{*}{ SED $^{1}$} & \multirow{2}{*}{$p$-Value } \\
\hline & Control & PA & OO & SBO & & \\
\hline $20: 0^{2}$ & 0.274 & 0.268 & 0.271 & 0.281 & 0.011 & 0.694 \\
\hline cis-8 $+920: 1$ & 0.011 & 0.010 & 0.010 & 0.011 & 0.001 & 0.069 \\
\hline cis-11 20:1 & $0.037^{b}$ & $0.036^{b}$ & $0.050^{\mathrm{a}}$ & $0.046^{\mathrm{a}}$ & 0.002 & $<0.001$ \\
\hline trans-11 20:1 & $0.003^{b}$ & $0.003^{b}$ & $0.008^{\mathrm{a}}$ & $0.006^{\mathrm{a}}$ & 0.001 & $<0.001$ \\
\hline $20: 2 n-6$ & $0.017^{a b}$ & $0.018^{a}$ & $0.015^{b}$ & $0.017^{a b}$ & 0.001 & 0.009 \\
\hline $20: 3 n-6$ & 0.024 & 0.025 & 0.022 & 0.026 & 0.002 & 0.233 \\
\hline $20: 3 n-3$ & 0.008 & 0.007 & 0.008 & 0.006 & 0.001 & 0.449 \\
\hline $20: 4 n-6$ & $0.152^{\mathrm{a}}$ & $0.149^{a}$ & $0.120^{b}$ & $0.146^{\mathrm{ab}}$ & 0.010 & 0.009 \\
\hline $20: 4 n-3$ & $0.001^{b}$ & $0.001^{b}$ & $0.001^{\mathrm{b}}$ & $0.003^{\mathrm{a}}$ & 0.000 & $<0.001$ \\
\hline $20: 5 n-3$ & $0.049 \mathrm{ab}$ & $0.058^{\mathrm{a}}$ & $0.042^{b}$ & $0.044^{b}$ & 0.004 & $<0.001$ \\
\hline $22: 0$ & $0.090^{\mathrm{ab}}$ & $0.078^{b c}$ & $0.075^{c}$ & $0.096^{\mathrm{a}}$ & 0.005 & $<0.001$ \\
\hline cis-13 22:1 & $0.003^{b}$ & $0.004^{b}$ & $0.004^{b}$ & $0.009^{\mathrm{a}}$ & 0.001 & $<0.001$ \\
\hline $22: 4 n-6$ & 0.021 & 0.021 & 0.017 & 0.022 & 0.002 & 0.058 \\
\hline $22: 5 n-6$ & $0.010^{\mathrm{ab}}$ & $0.014^{\mathrm{a}}$ & $0.008^{b}$ & $0.012^{\mathrm{a}}$ & 0.001 & 0.001 \\
\hline $22: 5 n-3$ & 0.088 & 0.098 & 0.083 & 0.088 & 0.008 & 0.312 \\
\hline $22: 6 n-3$ & 0.024 & 0.025 & 0.025 & 0.028 & 0.003 & 0.593 \\
\hline $24: 0$ & $0.037^{\mathrm{a}}$ & $0.031^{b}$ & $0.029^{b}$ & $0.032 \mathrm{ab}$ & 0.002 & 0.004 \\
\hline cis-15 24:1 & 0.010 & 0.009 & 0.008 & 0.007 & 0.001 & 0.192 \\
\hline$\sum$ C20-22 n-6 polyunsaturated fatty acids & $0.225^{\mathrm{ab}}$ & $0.229^{\mathrm{a}}$ & $0.189^{b}$ & $0.219 \mathrm{ab}$ & 0.014 & 0.034 \\
\hline$\sum$ C20-22 n-3 polyunsaturated fatty acids & 0.082 & 0.090 & 0.075 & 0.081 & 0.006 & 0.098 \\
\hline
\end{tabular}

${ }^{\mathrm{a}-\mathrm{c}}$ Within a row, different superscripts indicate differences $(p<0.05)$ due to the effect of diet. ${ }^{1} \mathrm{SED}=$ standard error of the difference. ${ }^{2}$ Coelutes with 18:3n-6.

Table 6. Milk odd- and branched-chain fatty acids ( $\mathrm{g} / 100 \mathrm{~g}$ of total fatty acids) in dairy ewes fed a total mixed ration without lipid supplementation (Control) or supplemented with $2 \%$ dry matter (DM) of palm distillate fatty acids (PA), olive oil (OO), and soybean oil (SBO).

\begin{tabular}{|c|c|c|c|c|c|c|}
\hline & \multicolumn{4}{|c|}{ Diet } & \multirow{2}{*}{ SED $^{1}$} & \multirow{2}{*}{$p$-Value } \\
\hline & Control & PA & OO & SBO & & \\
\hline $5: 0$ & 0.020 & 0.021 & 0.019 & 0.019 & 0.001 & 0.527 \\
\hline $7: 0$ & 0.045 & 0.044 & 0.040 & 0.045 & 0.003 & 0.341 \\
\hline $9: 0$ & 0.077 & 0.073 & 0.065 & 0.066 & 0.006 & 0.084 \\
\hline 11:0 & $0.124^{\mathrm{a}}$ & $0.107^{a b}$ & $0.085^{b}$ & $0.087^{b}$ & 0.010 & 0.001 \\
\hline anteiso 13:0 & $0.010^{a b}$ & $0.010^{\mathrm{a}}$ & $0.008^{b}$ & $0.008^{a b}$ & 0.001 & 0.019 \\
\hline iso 13:0 & $0.024^{\mathrm{a}}$ & $0.019^{a b}$ & $0.016^{\mathrm{b}}$ & $0.015^{\mathrm{b}}$ & 0.003 & 0.012 \\
\hline iso $14: 0$ & 0.099 & 0.093 & 0.081 & 0.078 & 0.008 & $0.031^{2}$ \\
\hline $15: 0$ & $0.938^{a}$ & $0.858^{a}$ & $0.711^{b}$ & $0.742^{b}$ & 0.033 & $<0.001$ \\
\hline anteiso 15:0 & $0.392^{\mathrm{a}}$ & $0.375^{a b}$ & $0.318^{c}$ & $0.329 \mathrm{bc}$ & 0.021 & 0.003 \\
\hline iso $15: 0^{3}$ & $0.219^{\mathrm{a}}$ & $0.199 \mathrm{ab}$ & $0.183^{b}$ & $0.175^{b}$ & 0.013 & 0.005 \\
\hline cis-9 15:1 & 0.011 & 0.010 & 0.009 & 0.010 & 0.001 & 0.303 \\
\hline trans- $6+7$ 15:1 & 0.020 & 0.021 & 0.017 & 0.020 & 0.002 & 0.080 \\
\hline iso $16: 0$ & $0.221^{\mathrm{a}}$ & $0.203^{a b}$ & $0.173^{b}$ & $0.200 \mathrm{ab}$ & 0.015 & 0.023 \\
\hline 4,8,12-trimethyl-13:0 & $0.056^{b}$ & $0.057^{\mathrm{b}}$ & $0.056^{\mathrm{b}}$ & $0.066^{\mathrm{a}}$ & 0.003 & 0.002 \\
\hline $17: 0$ & 0.516 & 0.511 & 0.456 & 0.466 & 0.022 & $0.016^{2}$ \\
\hline anteiso 17:0 & $0.420^{\mathrm{a}}$ & $0.406^{\mathrm{a}}$ & $0.353^{b}$ & $0.391^{\mathrm{ab}}$ & 0.017 & 0.003 \\
\hline iso $17: 0^{4}$ & 0.591 & 0.564 & 0.553 & 0.567 & 0.023 & 0.418 \\
\hline cis-9 17:1 & 0.173 & 0.176 & 0.147 & 0.148 & 0.012 & $0.030^{2}$ \\
\hline iso $18: 0$ & 0.048 & 0.049 & 0.037 & 0.042 & 0.006 & 0.149 \\
\hline
\end{tabular}


Table 6. Cont.

\begin{tabular}{|c|c|c|c|c|c|c|}
\hline & \multicolumn{4}{|c|}{ Diet } & \multirow{2}{*}{ SED $^{1}$} & \multirow{2}{*}{$p$-Value } \\
\hline & Control & PA & OO & SBO & & \\
\hline $19: 0^{5}$ & $0.088^{\mathrm{a}}$ & $0.080^{a b}$ & $0.075^{b}$ & $0.085^{a b}$ & 0.004 & 0.016 \\
\hline $21: 0^{6}$ & $0.071^{\mathrm{a}}$ & $0.064^{\mathrm{ab}}$ & $0.057^{b}$ & $0.060^{b}$ & 0.004 & 0.003 \\
\hline $23: 0$ & $0.064^{\mathrm{a}}$ & $0.052^{b}$ & $0.045^{b}$ & $0.047^{b}$ & 0.004 & $<0.001$ \\
\hline Eodd-chain fatty acids & $2.15^{\mathrm{a}}$ & $2.02^{\mathrm{a}}$ & $1.72^{b}$ & $1.80^{b}$ & 0.06 & $<0.001$ \\
\hline$\sum$ branched-chain fatty acids & $2.10^{\mathrm{a}}$ & $2.00 \mathrm{ab}$ & $1.78^{c}$ & $1.89 \mathrm{bc}$ & 0.06 & $<0.001$ \\
\hline
\end{tabular}

a-c Within a row, different superscripts indicate differences $(p<0.05)$ due to the effect of diet. ${ }^{1}$ SED $=$ standard error of the difference.

2 In the pairwise analysis, no significant differences were found after adjustment for multiple comparisons using Bonferroni's method.

3 Contains trans-9 14:1 as a minor isomer. ${ }^{4}$ Coelutes with cis-7 16:1. ${ }^{5}$ Coelutes with trans-9 trans-12 18:2. 6 Coelutes with trans-12 trans-14 CLA.

\section{Discussion}

In this study, lipids of different unsaturation degree were added to dairy ewe diet to test the hypothesis that unsaturated oils would modulate milk FA profile without impairing or even improving feed efficiency. To this aim, we examined the responses to 3 vegetable fats rich in saturated, monounsaturated, and polyunsaturated FA (i.e., 16:0, cis-9 18:1, and 18:2n-6, respectively). Although their main effects on milk FA profile have been previously described $[8,9,15]$, we report a comprehensive FA composition because available profiles in the literature are often poorly detailed, especially in terms of minor C18, odd-, branched-, and very long-chain FA. Although their biological effects are largely unknown [31-33], a lack of detail in presentation of results may limit the future advancement of knowledge or the potential application of FA as noninvasive biomarkers [22,34,35].

The use of 16:0-rich supplements, widely spread in cattle production, is increasingly common in dairy sheep farms under intensive conditions [5,15]. These fats are very effective at improving the energy density of the ration without negatively affecting nutrient digestibility [11,36], but their effects on milk FA profile might offer some drawbacks $[7,16,36]$. In our study, we observed an increment in the milk concentration of 16:0 with PA, consistent with expectations [7,15]. Although increasing 16:0 consumption might pose a greater risk of cardiovascular disease for human consumers $[37,38]$, such effect might be counteracted by the inversely proportional impact of PA on milk 14:0 and 12:0, which have also been reported to be atherogenic [39]. In addition, PA caused virtually no alteration in the concentration of other bioactive FA in milk, either potentially negative (e.g., trans-9 and trans-10 18:1) or positive (e.g., cis-9 trans-11 CLA and trans-11 18:1), in agreement with its potential inertness in the rumen and lower toxicity for microbiota than unsaturated FA $[36,40,41]$. Thus, our results would support that using palmitic-rich products in dairy sheep feeding has no evident disadvantage in terms of milk fat quality. Nevertheless, it does not appear to offer any advantage in terms of efficiency of feed utilization, according to the lack of variation in the studied metrics compared with the control, both in ratio traits (i.e., FCR and ECR) and in residual traits (i.e., RFI and REI).

Similarly, OO treatment had neither positive nor negative consequences on feed efficiency indicators, despite improvements in milk fat concentration and yield. We used olive oil as a model of fat rich in monounsaturated FA (specifically, cis-9 18:1), due to its easy and ready availability in most intensive dairy sheep production areas (in particular, in the Mediterranean basin) and its close FA profile to that of other lipid supplements widely studied in ruminant nutrition (e.g., rapeseed oil) [42-44]. Regarding the impact of $\mathrm{OO}$ on milk fat composition, it is worth highlighting some desirable effects, such as the decrease in medium-chain saturated FA and the increase in some potentially healthpromoting compounds, specifically 4:0, trans-11 18:1, cis-9 trans-11 CLA, and cis-9 18:1 [1,39]. The large variation in the latter would derive not only from dietary cis-9 18:1 supply, but also from its extensive saturation in the rumen [45,46], enhancing the availability of 18:0 for mammary $\Delta^{9}$-desaturation [47]. Ruminal cis-9 18:1 metabolism also involves isomerization and hydration/oxidation processes $[45,46]$, which would partly explain the increments 
in milk trans 18:1 and 10-oxo-18:0, respectively. In addition, changes in 18:1 isomers may also derive from a greater biohydrogenation extent of $18: 2 n-6$ and 18:3n-3, as suggested by the drop in their milk concentration. This effect on biohydrogenation extent has been consistently described in studies on ruminal metabolism when unsaturated FA supplements are provided [46,48]. On the contrary, certain effects of OO on milk FA profile were less desirable, in particular the increase in trans-9 and trans-10 18:1 or the decrease in branchedchain FA, which would be explained by direct isomerization of cis-9 18:1 in the rumen or inhibition of microbial de novo FA synthesis, respectively [35,40,45].

Among the treatments studied, SBO showed the best potential to modulate milk FA profile. Compared with OO, it induced even greater improvements in cis-9 trans-11 CLA and trans-11 18:1 concentrations, with similar variations in medium-chain saturates and other potentially bioactive FA (e.g., 4:0 and trans-10 18:1). Moreover, SBO improved 18:2n-6 and had no negative effect on 18:3n-3. Although this may increase the n-6/n-3 FA ratio in milk, the implications of this index for human health are under debate, and focusing attention on improving the consumption of both types of polyunsaturated FA is increasingly encouraged $[49,50]$. On the other hand, SBO was the only treatment that raised milk trans-10 cis-12 CLA content, but its final proportion was actually marginal $(0.006 \%$ of total FA) and, therefore, no MFD was induced. A recent meta-analysis has indeed shown that much higher trans-10 cis-12 CLA concentrations may be reached $(\sim 0.031 \%$ of total FA) without risk of MFD in sheep fed high-concentrate diets and plant oils, given their ability to compensate the inhibition of de novo FA synthesis by enhanced preformed FA yield [51].

In addition, the reduction in FCR with SBO suggests an improvement in the efficiency of feed utilization compared with the Control and PA treatments. In this regard, the comparison between $\mathrm{SBO}$ and PA is particularly interesting, as they are isoenergetic diets. This would explain the consistency in the SBO vs. PA comparison when the ECR was employed, an indicator that is estimated using the net energy intake, whereas the FCR is based on DM intake $[18,26]$. Thus, ECR seems more convenient in our study because it avoids the bias associated to the different energy density of our experimental diets [26]. However, when residual traits (RFI and REI) were examined, no variation was detected and responses to supplemented treatments did not follow a similar pattern to that observed with ratio traits.

Residual traits are currently more recommended and used as indicators of feed efficiency in genetic selection $[19,22,27]$; their interest deriving from their potential relationship with basic metabolic processes [52,53]. In Australia, steers from low-RFI selection lines have been shown to consume less feed for the same level of growth performance and, thus, improve the profitability of farms [24]. Nevertheless, from a productive point of view and with the perspective of a direct application in the dairy sector, decreased FCR and ECR would also entail economic advantages for farmers, thus the potentially positive implications of our findings. Furthermore, animal performance data suggest that the lower FCR and ECR in SBO would partly be explained by increased FA yield, which supports a key role of lipid metabolism in underlying feed efficiency mechanisms [22,54]. Further, note that our results did not seem to be explained by mobilization of body reserves, since all treatments showed improved body weight during the trial.

Finally, regarding a validation of previously suggested biomarkers of feed efficiency in dairy ewes (e.g., saturated C4-C14 FA, saturated C4-C14 fatty acids/cis-9 18:1 ratio or C20-22 n-6 polyunsaturated FA in milk) [22], no solid conclusions can be drawn. The reason is none other than the divergent effects of experimental diets on the milk concentration of these biomarkers. Thus, for example, $\mathrm{OO}$ and SBO treatments caused both increases and decreases in individual even-chain saturated C4-C14 FA, which may bias their total amount in milk. In addition, the improvement in cis-9 18:1 concentration in the same treatments would be explained by the additional dietary supply of this monounsaturated FA and the greater mammary availability of its precursor, 18:0, rather than a greater mobilization of adipose tissue (rich in cis-9 18:1) in animals under negative energy balance [55,56]. Therefore, treatment differences in saturated C4-C14 fatty acids/cis-9 18:1 ratio cannot actually be related to potential variations in feed efficiency when animals fed different lipid 
supplements are compared [22]. In any event, the results of this experimental trial would not undermine the application of suggested biomarkers in dairy sheep farms, where all lactating ewes would be offered the same diet. Otherwise, discriminating animals by feed efficiency level should be conducted independently within each dietary condition.

\section{Conclusions}

Overall, our results support the initial hypothesis that unsaturated lipid supplements modulate milk FA profile in dairy sheep without impairing or even improving feed efficiency. Compared with a saturated fat rich in 16:0 (palm distillate FA), addition of a source of monounsaturated FA (olive oil) decreases medium-chain saturated FA in milk and improves the concentration of potentially health promoting FA, such as cis-9 18:1, trans-11 18:1, cis-9 trans-11 CLA, and 4:0, with no impact on feed efficiency indicators. Nevertheless, results of FA analysis and decreases in FCR and ECR suggest that using soybean oil supplementation would be a more convenient nutritional strategy to achieve further improvements in milk FA profile and also in feed efficiency in dairy ewes. However, the paradox of differences observed depending on the metric used to estimate feed efficiency (i.e., the lack of variation in residual traits-RFI and REI-vs. changes in ratio traits-FCR and ECR) does not allow solid conclusions to be drawn in this regard.

Author Contributions: Conceptualization, G.H., P.G.T. and P.F.; data curation, G.H. and P.G.T.; formal analysis, G.H., P.G.T., C.F.-D. and A.D.B.; funding acquisition, P.F.; investigation, G.H., P.G.T., C.F.-D. and P.F.; methodology, G.H., P.G.T., C.F.-D. and P.F.; project administration, P.F.; writing-original draft preparation, G.H., P.G.T. and P.F.; writing-review and editing, C.F.-D. and A.D.B. All authors have read and agreed to the published version of the manuscript.

Funding: This research was funded by the Junta de Castilla y León (JCyL, Spain; project CSI276P18). P.G. Toral benefited from a Ramón y Cajal research contract from the Spanish Ministry of Economy and Competitiveness (MINECO; RYC-2015-17230), C. Fernández-Díez from a postdoctoral research contract from JCyL and A. Della Badia from a FPI predoctoral contract from the Spanish Ministry of Science and Innovation (MICINN; PRE2018-086174). Co-funding by the European Regional Development Fund (ERDF/FEDER) and the European Social Fund (ESF) is also acknowledged.

Institutional Review Board Statement: All experimental procedures were performed in accordance with European Union and Spanish legislations (Council Directive 2010/63/EU and R. D. 53/2013), being approved by the Research Ethics Committees of the Instituto de Ganadería de Montaña (CSICULE), the Spanish National Research Council (CSIC), and the JCyL, Spain (code 649/2018).

Conflicts of Interest: The authors declare no conflict of interest.

\section{References}

1. Shingfield, K.J.; Chilliard, Y.; Toivonen, V.; Kairenius, P.; Givens, D.I. Trans Fatty Acids and Bioactive Lipids in Ruminant Milk. Adv. Exp. Med. Biol. 2008, 606, 3-65. [CrossRef]

2. Gómez-Cortés, P.; Frutos, P.; Mantecón, A.R.; Juárez, M.A.; de la Fuente, M.; Hervás, G. Effect of supplementation of grazing dairy ewes with a cereal concentrate on animal performance and milk fatty acid profile. J. Dairy Sci. 2009, 92, 3964-3972. [CrossRef]

3. Nudda, A.; Cannas, A.; Correddu, F.; Atzori, A.S.; Lunesu, M.F.; Battacone, G.; Pulina, G. Sheep and goats respond differently to feeding strategies directed to improve the fatty acid profile of milk fat. Animals 2020, 10, 1290. [CrossRef]

4. Mele, M.; Buccioni, A.; Serra, A. Lipid requirements in the nutrition dairy ewes. Ital. J. Anim. Sci. 2005, 4, 53-62. [CrossRef]

5. Gargouri, A.; Caja, G.; Casals, R.; Mezghani, I. Lactational evaluation of effects of calcium soap of fatty acids on dairy ewes. Small Rumin. Res. 2006, 66, 1-10. [CrossRef]

6. Palmquist, D.L.; Jenkins, T.C. A 100-Year Review: Fat feeding of dairy cows. J. Dairy Sci. 2017, 100, 10061-10077. [CrossRef]

7. Bodas, R.; Manso, T.; Mantecón, A.R.; Juárez, M.; de la Fuente, M.A.; Gómez-Cortés, P. Comparison of the fatty acid profiles in cheeses from ewes fed diets supplemented with different plant oils. Agric. Food Chem. 2010, 58, 10493-10502. [CrossRef] [PubMed]

8. Castro-Carrera, T.; Frutos, P.; Leroux, C.; Chilliard, Y.; Hervás, G.; Belenguer, A.; Bernard, L.; Toral, P.G. Dietary sunflower oil modulates milk fatty acid composition without major changes in adipose and mammary tissue fatty acid profile or related gene mRNA abundance in sheep. Animal 2015, 9, 582-591. [CrossRef] [PubMed]

9. Vargas-Bello-Pérez, E.; Darabighane, B.; Miccoli, F.E.; Gómez-Cortés, P.; Gonzalez-Ronquillo, M.; Mele, M. Effect of Dietary Vegetable Sources Rich in Unsaturated Fatty Acids on Milk Production, Composition, and Cheese Fatty Acid Profile in Sheep: A Meta-Analysis. Front. Vet. Sci. 2021, 8, 641364. [CrossRef] [PubMed] 
10. Rico, J.E.; Allen, M.S.; Lock, A.L. Compared with stearic acid, palmitic acid increased the yield of milk fat and improved feed efficiency across production level of cows. J. Dairy Sci. 2014, 97, 1057-1066. [CrossRef] [PubMed]

11. De Souza, J.; Preseault, C.L.; Lock, A.L. Altering the ratio of dietary palmitic, stearic, and oleic acids in diets with or without whole cottonseed affects nutrient digestibility, energy partitioning, and production responses of dairy cows. J. Dairy Sci. 2018, 101, 172-185. [CrossRef]

12. Bauman, D.E.; Griinari, J.M. Regulation and nutritional manipulation of milk fat: Low-fat milk syndrome. Livest. Prod. Sci. 2001, 70, 15-29. [CrossRef]

13. Parente, M.O.M.; Susin, I.; Nolli, C.P.; Ferreira, E.M.; Gentil, R.S.; Polizel, D.M.; Pires, A.V.; Alves, S.P.; Bessa, R.J.B. Effects of supplementation with vegetable oils, including castor oil, on milk production of ewes and on growth of their lambs. J. Anim. Sci. 2018, 96, 354-363. [CrossRef] [PubMed]

14. Mele, M.; Buccioni, A.; Petacchi, F.; Serra, A.; Banni, S.; Antongiovanni, M.; Secchiari, P. Effect of forage/concentrate ratio and soybean oil supplementation on milk yield, and composition from Sarda ewes. Anim. Res. 2006, 55, 273-285. [CrossRef]

15. Castro, T.; Manso, T.; Jimeno, V.; Del Alamo, M.; Mantecón, A.R. Effects of dietary sources of vegetable fats on performance of dairy ewes and conjugated linoleic acid (CLA) in milk. Small Rumin. Res. 2009, 84, 47-53. [CrossRef]

16. Kliem, K.E.; Shingfield, K.J.; Humphries, D.J.; Givens, D.I. Effect of replacing calcium salts of palm oil distillate with incremental amounts of conventional or high oleic acid milled rapeseed on milk fatty acid composition in cows fed maize silage-based diets. Animal 2011, 5, 1311-1321. [CrossRef]

17. Wilkinson, J.M. Re-defining efficiency of feed use by livestock. Animal 2011, 5, 1014-1022. [CrossRef]

18. Cantalapiedra-Hijar, G.; Abo-Ismail, M.; Carstens, G.E.; Guan, L.L.; Hegarty, R.; Kenny, D.A.; McGee, M.; Plastow, G.; Relling, A.; Ortigues-Marty, I. Review: Biological determinants of between-animal variation in feed efficiency of growing beef cattle. Animal 2018, 12, s321-s335. [CrossRef]

19. Løvendahl, P.; Difford, G.F.; Li, B.; Chagunda, M.G.G.; Huhtanen, P.; Lidauer, M.H.; Lassen, J.; Lund, P. Review: Selecting for improved feed efficiency and reduced methane emissions in dairy cattle. Animal 2018, 12, s336-s349. [CrossRef]

20. Marie, C.; Barillet, F.; Such, X.; Bocquier, F.; Caja, G. Feed efficiency of dairy ewes according to milk genetic merit. Options Méditerr. B 2002, 42, 57-71.

21. González-García, E.; Santos, J.P.D.; Hassoun, P. Residual feed intake in dairy ewes: An evidence of intraflock variability. Animals 2020, 10, 1593. [CrossRef]

22. Toral, P.G.; Hervás, G.; Fernández-Díez, C.; Belenguer, A.; Frutos, P. Rumen biohydrogenation and milk fatty acid profile in dairy ewes divergent for feed efficiency. J. Dairy Sci. 2021, 104, 5569-5582. [CrossRef] [PubMed]

23. Connor, E.E.; Hutchison, J.L.; Olson, K.M.; Norman, H.D. Triennial Lactation Symposium: Opportunities for improving milk production efficiency in dairy cattle. J. Anim. Sci. 2012, 90, 1687-1694. [CrossRef] [PubMed]

24. Arthur, P.F.; Pryce, J.E.; Herd, R.M. Lessons learnt from 25 years of feed efficiency research in Australia. In Proceedings of the 10th World Congress of Genetics Applied to Livestock Production (WCGALP), Vancouver, BC, Canada, 17-22 August 2014.

25. INRA. Alimentation des Ruminants; Editions Quae: Versailles, France, 2018.

26. Hurley, A.M.; Lopez-Villalobos, N.; McParland, S.; Kennedy, E.; Lewis, E.; O’Donovan, M.; Burke, J.L.; Berry, D.P. Interrelationships among alternative definitions of feed efficiency in grazing lactating dairy cows. J. Dairy Sci. 2016, 99, 468-479. [CrossRef] [PubMed]

27. Pryce, J.E.; Gonzalez-Recio, O.; Nieuwhof, G.; Wales, W.J.; Coffey, M.P.; Hayes, B.J.; Goddard, M.E. Hot topic: Definition and implementation of a breeding value for feed efficiency in dairy cows. J. Dairy Sci. 2015, 98, 7340-7350. [CrossRef]

28. Shingfield, K.J.; Ahvenjärvi, S.; Toivonen, V.; Ärölä, A.; Nurmela, K.V.V.; Huhtanen, P.; Griinari, J.M. Effect of dietary fish oil on biohydrogenation of fatty acids and milk fatty acid content in cows. Anim. Sci. 2003, 77, 165-179. [CrossRef]

29. Bichi, E.; Hervás, G.; Toral, P.G.; Loor, J.J.; Frutos, P. Milk fat depression induced by dietary marine algae in dairy ewes: Persistency of milk fatty acid composition and animal performance responses. J. Dairy Sci. 2013, 96, 524-532. [CrossRef]

30. Toral, P.G.; Hervás, G.; Carreño, D.; Leskinen, H.; Belenguer, A.; Shingfield, K.J.; Frutos, P. In vitro response to EPA, DPA, and DHA: Comparison of effects on ruminal fermentation and biohydrogenation of 18-carbon fatty acids in cows and ewes. J. Dairy Sci. 2017, 100, 6187-6198. [CrossRef]

31. Wang, Y.; Proctor, S.D. Current issues surrounding the definition of trans-fatty acids: Implications for health, industry and food labels. Br. J. Nutr. 2013, 110, 1369-1383. [CrossRef]

32. Ran-Ressler, R.R.; Bae, S.; Lawrence, P.; Wang, D.H.; Thomas Brenna, J. Branched-chain fatty acid content of foods and estimated intake in the USA. Br. J. Nutr. 2014, 112, 565-572. [CrossRef]

33. Dewanckele, L.; Toral, P.G.; Vlaeminck, B.; Fievez, V. Invited review: Role of rumen biohydrogenation intermediates and rumen microbes in diet-induced milk fat depression: An update. J. Dairy Sci. 2020, 103, 7655-7681. [CrossRef]

34. Moate, P.J.; Chalupa, W.; Boston, R.C.; Lean, I.J. Milk Fatty Acids. I. Variation in the Concentration of Individual Fatty Acids in Bovine Milk. J. Dairy Sci. 2007, 90, 4730-4739. [CrossRef]

35. Fievez, V.; Colman, E.; Castro-Montoya, J.M.; Stefanov, I.; Vlaeminck, B. Milk odd- and branched-chain fatty acids as biomarkers of rumen function-An update. Anim. Feed Sci. Technol. 2012, 172, 51-65. [CrossRef]

36. Rico, D.E.; Ying, Y.; Harvatine, K.J. Effect of a high-palmitic acid fat supplement on milk production and apparent total-tract digestibility in high- and low-milk yield dairy cows. J. Dairy Sci. 2014, 97, 3739-3751. [CrossRef] [PubMed] 
37. Kliem, K.E.; Shingfield, K.J. Manipulation of milk fatty acid composition in lactating cows: Opportunities and challenges. Eur. J. Lipid Sci. Technol. 2016, 118, 1661-1683. [CrossRef]

38. Temme, E.H.M.; Mensink, R.P.; Hornstra, G. Comparison of the effects of diets enriched in lauric, palmitic, or oleic acids on serum lipids and lipoproteins in healthy women and men. Am. J. Clin. Nutr. 1996, 63, 897-903. [CrossRef] [PubMed]

39. Parodi, P.W. Has the Association between saturated fatty acids, serum cholesterol and coronary heart disease been over emphasized? Int. Dairy J. 2009, 19, 345-361. [CrossRef]

40. Lourenço, M.; Ramos-Morales, E.; Wallace, R.J. The role of microbes in rumen lipolysis and biohydrogenation and their manipulation. Animal 2010, 4, 1008-1023. [CrossRef]

41. Enjalbert, F.; Combes, S.; Zened, A.; Meynadier, A. Rumen microbiota and dietary fat: A mutual shaping. J. Appl. Microbiol. 2017, 123, 782-797. [CrossRef]

42. Gómez-Cortés, P.; Frutos, P.; Mantecon, A.R.; Juarez, M.; De La Fuente, M.A.; Hervás, G. Addition of Olive Oil to Dairy Ewe Diets: Effect on Milk Fatty Acid Profile and Animal Performance. J. Dairy Sci. 2008, 91, 3119-3127. [CrossRef]

43. Rego, O.A.; Alves, S.P.; Antunes, L.M.S.; Rosa, H.J.D.; Alfaia, C.F.M.; Prates, J.A.M.; Cabrita, A.R.J.; Fonseca, A.J.M.; Bessa, R.J.B. Rumen biohydrogenation-derived fatty acids in milk fat from grazing dairy cows supplemented with rapeseed, sunflower, or linseed oils. J. Dairy Sci. 2009, 92, 4530-4540. [CrossRef] [PubMed]

44. Szumacher-Strabel, M.; Cieslak, A.; Nowakowska, A.; Potkanski, A. The effect of rapeseed oil and a combination of linseed and fish oils in the diets for sheep on milk fatty acid profile. Zuchtungskunde 2008, 80, 412-419.

45. Mosley, E.E.; Powell, G.L.; Riley, M.B.; Jenkins, T.C. Microbial biohydrogenation of oleic acid to trans isomers in vitro. J. Lipid Res. 2002, 43, 290-296. [CrossRef]

46. Toral, P.G.; Hervás, G.; Peiró, V.; Frutos, P. Conditions Associated with Marine Lipid-Induced Milk Fat Depression in Sheep Cause Shifts in the In Vitro Ruminal Metabolism of 1-13C Oleic Acid. Animals 2018, 8, 196. [CrossRef] [PubMed]

47. Bernard, L.; Leroux, C.; Chilliard, Y. Expression and nutritional regulation of stearoyl-CoA desaturase genes in the ruminant mammary gland: Relationship with milk fatty acid composition. In Stearoyl-CoA Desaturase Genes in Lipid Metabolism; Ntambi, J.M., Ed.; Springer Science+Business Media: New York, NY, USA, 2013; pp. 161-194.

48. Kairenius, P.; Leskinen, H.; Toivonen, V.; Muetzel, S.; Ahvenjärvi, S.; Vanhatalo, A.; Huhtanen, P.; Wallace, R.J.; Shingfield, K.J. Effect of dietary fish oil supplements alone or in combination with sunflower and linseed oil on ruminal lipid metabolism and bacterial populations in lactating cows. J. Dairy Sci. 2018, 101, 3021-3035. [CrossRef]

49. Wijendran, V.; Hayes, K.C. Dietary n-6 and n-3 fatty acid balance and cardiovascular health. Annu. Rev. Nutr. 2004, 24, 597-615. [CrossRef]

50. Salter, A.M. Dietary fatty acids and cardiovascular disease. Animal 2013, 7, 163-171. [CrossRef]

51. Toral, P.G.; Gervais, R.; Hervás, G.; Létourneau-Montminy, M.P.; Frutos, P. Relationships between trans-10 shift indicators and milk fat traits in dairy ewes: Insights into milk fat depression. Anim. Feed. Sci. Technol. 2020, 261, 114389. [CrossRef]

52. Korver, S. Genetic aspects of feed intake and feed efficiency in dairy cattle: A review. Livest. Prod. Sci. 1988, 20, 1-13. [CrossRef]

53. Archer, J.A.; Richardson, E.C.; Herd, R.M.; Arthur, P.F. Potential for selection to improve efficiency of feed use in beef cattle: A review. Aust. J. Agric. Res. 1999, 50, 147-161. [CrossRef]

54. Artegoitia, V.M.; Foote, A.P.; Lewis, R.M.; Freetly, H.C. Rumen fluid metabolomics analysis associated with feed efficiency on crossbred steers. Sci. Rep. 2017, 7, 14. [CrossRef] [PubMed]

55. Dórea, J.R.R.; French, E.A.; Armentano, L.E. Use of milk fatty acids to estimate plasma nonesterified fatty acid concentrations as an indicator of animal energy balance. J. Dairy Sci. 2017, 100, 6164-6176. [CrossRef] [PubMed]

56. Khiaosa-ard, R.; Kleefisch, M.-T.; Zebeli, Q.; Klevenhusen, F. Milk fatty acid composition reflects metabolic adaptation of early lactation cows fed hay rich in water-soluble carbohydrates with or without concentrates. Anim. Feed Sci. Technol. 2020, 264, 114470. [CrossRef] 